\title{
Cities' attraction and retention of graduates: a more-than-economic approach
}

\author{
Lena Imeraj ${ }^{1}$, Didier Willaert ${ }^{2}$, Nissa Finney ${ }^{3}$ and Sylvie Gadeyne ${ }^{4}$
}

Interface Demography, Department of Sociology, Vrije Universiteit Brussel, Pleinlaan 2, 1050 Brussels, Belgium. Tel: +32 26148124 Email: Lena.Imeraj@vub.be

${ }^{2}$ Interface Demography, Department of Sociology, Vrije Universiteit Brussel, Pleinlaan 2, 1050 Brussels, Belgium. Tel:+32 26148130 Email: Didier.Willaert@vub.be

${ }^{3}$ Department of Geography and Sustainable Development and CoDE, ESRC Centre on Dynamics of Ethnicity, Irvine Building, University of St Andrews, KY16 9AL, United Kingdom. Tel: +4401334463944 Email: nf42@st-andrews.ac.uk

'Interface Demography, Department of Sociology, Vrije Universiteit Brussel, Pleinlaan 2, 1050 Brussels, Belgium. Tel: +32 26148150 Email: Sylvie.Gadeyne@vub.be

All correspondence to:

Lena Imeraj

Vrije Universiteit Brussel

Department of Sociology - Interface Demography

Pleinlaan 2

1050 Brussels, Belgium

Email: Lena.Imeraj@vub.be 


\begin{abstract}
In skilled migration research, the role of the study location in graduates' residential behaviour remains unclear. This paper addresses this lacuna by examining the attractiveness and retention of higher education cities for local attendants in the period after study, using Belgium as an empirical case study. Drawing on a unique linkage of census and register data for 1991-2010, logistic and Cox regressions illustrate the relative success of smaller cities once individual, familial and contextual factors are considered. Location-specific characteristics beyond the economic are found to shape skilled migration towards the higher education localities, particularly in the short term.
\end{abstract}

Keywords: internal migration, location-specific capital, graduates, higher education cities, Belgium

JEL Codes: I21 - Analysis of Education < I2 - Education and Research Institutions < I Health, Education, and Welfare; J24 - Human Capital|Skills $\mid$ Occupational Choice|Labor Productivity < J2 - Demand and Supply of Labor < J - Labor and Demographic Economics; R11 - Regional Economic Activity: Growth, Development, Environmental Issues, and Changes < R1 - General Regional Economics < R - Urban, Rural, Regional, Real Estate, and Transportation Economics; R23 - Regional Migration; Regional Labor Markets; Population; Neighborhood Characteristics < R2 - Household Analysis < R - Urban, Rural, Regional, Real Estate, and Transportation Economics 


\section{Introduction}

Over recent decades, theoretical models and empirical analyses within human capital mobility research numerously studied the drivers and consequences of skilled migration, internationally and regionally (Fratesi, 2014). Concentrating on drivers at the regional level, research has identified important individual and contextual determinants of the residential behaviour of the highly skilled, mainly from an economic perspective. One strand of literature focusses on the role that Higher Educational Institutions (HEIs) hold in producing and mobilizing human capital (e.g. Baryla \& Dotterweich, 2001; Venhorst, Van Dijk \& Van Wissen, 2010). However, skilled migration in relation to HEIs is mostly considered as driven by labour market opportunities (and wages). In this paper, we argue that other non-tradable non-economic factors, particularly location-specific capital, need to be accounted for. This can provide a useful perspective for those concerned with spatial fragmentation and decreasing quality of life in urban centres (Poelmans \& Van Rompaey, 2009).

Cities benefit from the presence of skilled people. As skilled people have acquired high levels of human capital, tend to have above average incomes and, therefore, pay higher taxes. In this respect, cities of Higher Education (HE) are of great interest. University graduates remain in their study region when it is a central region of a metropolitan city - generally with a strong labour market offering ample job opportunities - but have higher propensities to leave when the place of study is peripheral (Baryla \& Dotterweich, 2001; Dotti, Fratesi, Lenzi \& Percoco, 2013; Haapanen \& Tervo, 2012; Hoare \& Corver, 2010; Krabel \& Flöther, 2014; Venhorst et al., 2010). It is doubtful, however, that locally produced knowledge will remain in the city merely because of a strong local economy. The relative importance of local amenities as a pull factor - as suggested by Biagi, Faggian \& McCann (2011) - might be underestimated, especially in the case of Belgium, where long-distance migration is rather uncommon due to the small scale and the highly urbanised and dense landscape. Knowledge of the mediating role of the HE location beyond the local labour market structure in the residential behaviour of young graduates remains insufficient. This paper argues that non-economic characteristics of the study region too often are left aside, yet potentially shape the residential mobility of the highly educated more than is generally acknowledged. Hence, it aims partially to fill this gap by building on the concept of "location-specific capital” (Davanzo, 1983, p.553), 
using Belgium as a case study. It is hypothesized that the acquaintance and familiarity with the local environment of the HEI, rather than merely the job opportunities, facilitates a future move of recent $\mathrm{HE}$ attendants towards HE cities.

This hypothesis is tested by analysing the residential behaviour of young adults in the decade after their HE study using information from individual longitudinal census data from 1991 and 2001 linked to register data on geographical mobility between 2001 and 2010. Analyses illustrate the attractiveness of smaller cities for former attendants of the local HEI; individual characteristics and the acquaintance with the local area seem important determinants in the settlement of young skilled individuals, irrespective of the broader labour or housing market conditions.

\section{Human capital on the move: some determinants}

Increased levels of education and intensified residential mobility among the highly educated has expanded the importance of human capital mobility in contemporary societies (Butler \& Hamnett, 2007). The high residential mobility of young university and college graduates has been shown to be crucial for the process of human and financial capital redistribution (e.g. Faggian \& McCann, 2009).

Graduation and entry into the labour market are decisive moments when it comes to migration of young adults (Feijten \& Mulder, 2002; Kley \& Mulder, 2010). Spatial mobility among the highly skilled is particularly directed towards urban regions functioning as economic and social attraction pools and offering affordable rental housing (Florida, 2002; Venhorst, Van Dijk \& Van Wissen, 2011; Whisler, Waldorf, Mulligan \& Plane, 2008). As job opportunities are often the primary driving force of migration during the first years after graduation, the poorer opportunities in peripheral regions of origin theoretically impose a large motivation for migration to central (urban) opportunity-rich areas with well-paid jobs (Borjas, Bronars \& Trejo, 1992; Haapanen \& Tervo, 2012). A highly urbanised and dense environment, such as Belgium, however, creates a context in which people do not feel obliged to migrate towards or live in the urban environment in order to work there. Graduates either are attracted initially but leave the city towards the suburbs as they start having a family or higher earnings, or immediately settle in the suburbs where urban employees commute to work on a daily basis (Kulu \& Milewski, 2007; Verhetsel, Thomas \& Beelen, 2010). The loss of the most skilled, whether 
immediate or postponed, is detrimental: losing above-average skills and incomes weakens economic growth and raises the tax burden for the remaining city-dwellers (Böckerman \& Haapanen, 2013) ${ }^{\prime}$. Their employment in the city or their contribution to the local economy through intensive use of urban amenities, do not safeguard major cities from reduced fiscal incomes as non-residents do not contribute directly to local (city) taxes (Verhetsel et al., 2010). Although many services are administered and funded by central and regional governments, the generation of revenue via local taxes determines cities' abilities to provide services such as road maintenance, social security, housing and education.

HEIs can play a valuable role in determining the attractiveness and affluence of cities. Location-specific amenities offered in these urban contexts include natural amenities (Graves, 1980), manmade amenities (Blomquist, Berger \& Hoehn, 1988) and social, cultural and skill-dependent amenities (Florida, 2002). Conditional on the extent to which different amenities are satisfactory, people are more or less likely to prefer a particular destination (Whisler et al., 2008). Given that psychological costs of migration are reduced through knowledge of local facilities, proximity of relatives and availability of information (Coniglio \& Prota, 2008; Delisle \& Shearmur, 2010), the regional familiarity with the former location of the HEI could matter significantly to graduates' propensity to settle in the city of HE after getting a degree. Hence, 'location-specific capital' (Davanzo, 1983, p.553) - built up as social networks and knowledge of local facilities and amenities through residential experience during HE study - eases the move (Venhorst, 2013). In this paper, it is argued that residence close to the $\mathrm{HE}$ city or residence in student accommodation provides better opportunities to acquire this location-specific capital, linked to environmental, social and cultural characteristics (e.g. Delisle \& Shearmur, 2010; Whisler et al., 2008). Consequently, settlement in the former HE area allows recent graduates to recoup and reuse a part of the location-specific advantages acquired, thereby preventing the loss of value of their investment in close friends and knowledge of local circumstances (DaVanzo, 1983).

To disentangle the variable role of study location and local acquaintance, this paper accounts for determinants described in earlier studies on skilled migration. These have

\footnotetext{
1 Cities' surcharges - based on one's fiscal income and immovable property - raised in an attempt to reduce fiscal shortages, thereby substantially adding to the fiscal burden for stayers (Devogelaer, 2004).
} 
illustrated how a graduate's decision to migrate is subject to individual characteristics such as gender (Faggian, McCann \& Sheppard, 2007), ethnicity (Faggian, McCann \& Sheppard, 2006) and discipline or type of HE (Faggian, Comunian, Jewell \& Kelly, 2013; Venhorst et al., 2010), as well as to pull factors that relate to economic aspects of the destination area, such as the unemployment rate, the existence of a knowledge-economy or interregional wage differentials (Buch, Hamann, Niebuhr \& Rossen, 2013; Dotti et al., 2013).

There is a dearth of research focusing specifically on the role of location-specific capital in relation to graduate migration. The purpose of this study is partially to address this gap by assessing the impact of the study region on graduates' residential mobility, accounting for individual and parental characteristics, and for contextual features.

\section{Data and methods}

This study uses inter-linked Belgian 1991 (1 March 1991) and 2001 (1 October 2001) census data, and register data on residential changes and deaths between 1 January 2001 and 1 January 2010 for the entire de jure population. The selected population consists of students in full-time $\mathrm{HE}$ on 1/10/2001, providing information on the HEI location and student accommodation. In the absence of a direct measurement of graduation, we aim to maximize the completion rate within the sample by restricting analyses to students in the final stages of their HE programme, i.e. students aged 20-24 years in a (professional) bachelor/undergraduate programme or aged 21-25 years in other types of HE. The age criterion excludes a small proportion of students who are older and whose socioeconomic and demographic characteristics differ considerably from those of the younger students (1.6\%). Students who are not officially domiciled with their parents at the time of their studies $(6.0 \%)$ and doctoral students are excluded for similar reasons. Students enrolled in more than one HE type $(0.1 \%)$ are excluded to avoid double counting. The final selection comprises 82,549 students (subsequently also referred to as 'graduates') with a valid HEI location in Belgium.

Logistic regression and Cox modelling are used to estimate the attractiveness and retention capacity of $\mathrm{HE}$ cities as a residential destination for recent local students. Our main explanatory variable - HE City - is based on the reported location of $\mathrm{HE}$ attendance in 2001. Analyses focus on the largest and most important HE cities, defined 
by LAU-2 units or municipalities (Eurostat's system of Local Administrative Units is illustrated in Appendix A); smaller cities are grouped together. This results in the following classification: Brussels-Capital Region (BCR), Antwerp, Ghent, Liège, Charleroi, Leuven, Hasselt, Mons, Namur, Louvain-la-Neuve, other regional cities and other smaller cities. To allow representative comparisons, all 19 Brussels municipalities ${ }^{2}$ are grouped into a single geographical unit.

Location-specific capital refers to the acquired familiarity with the area through residential experience or having studied in the city, leading to knowledge of local circumstances and to networks of close friends (DaVanzo, 1983; Venhorst, 2013). The concept is approximated by measures of residential proximity to the HEI location. Student accommodation - StudAcc - in Belgium chiefly comprises rooms in private properties, rented from landlords or from the educational institution on an individual basis. Despite living in student accommodation, it is a national habit that students generally remain officially registered at the address of the parents during their HE. The comparison of the HEI location, the official residence and the location of daily departure allows the distinction between being in student accommodation or not. Residence in 2001 - Res01 - is based on the official address of the parents at the LAU-2 level on 1/10/2001 and separates students living in the HE city from those officially domiciled elsewhere. Furthermore, the degree of urbanisation - Urban01 - of the 2001 residence is considered, distinguishing the central city, agglomeration, banlieue, commuterzone and other municipalities (LAU-2) (Van Hecke, Halleux, Decroly \& Mérenne-Schoumaker, 2009).

In line with the abovementioned determinants in skilled migration literature, a number of socio-economic and demographic characteristics have been included as control factors. EduPar considers the educational level of the most educated parent ${ }^{3}$ (only one in cases of a single parent household) and differentiates between low (no formal, primary, lower secondary), intermediate (higher secondary), high (tertiary) and unknown education. The occupational status of the father (or mother in the case of a single mother household) OccupStat - recodes 14 response categories into five groups: blue-collar, white-collar, self-

\footnotetext{
2 Anderlecht, Oudergem, Sint-Agatha-Berchem, Brussel, Etterbeek, Evere, Vorst, Ganshoren, Elsene, Jette, Koekelberg, Sint-Jans-Molenbeek, Sint-Gillis, Sint-Joost-ten-Node, Schaarbeek, Ukkel, WatermaalBosvoorde, Sint-Lambrechts-Woluwe, Sint-Pieters-Woluwe.

3 Parents are distinguished on the basis of the young adult's household composition in 1991 and 2001. Educational information for parents is derived from the 2001 census or the 1991 censuses in case of incomplete or missing educational information.
} 
employed/managerial, unemployed and unknown occupational status. The type of tertiary training - HE Type - distinguishes professional bachelors, academic bachelors, academic masters and postgraduate masters (i.e. additional degree to tertiary qualification).

Demographic measures are origin, age and sex. The nationality of origin - NatOrig is defined based on the nationality at birth and the current nationality of both parents, thereby identifying first as well as second generation migrants. NatOrig distinguishes Belgian, Turkish/Moroccan (including North-African and Middle-Eastern), SouthEuropean, Western and non-Western (including former Communist countries) respondents. This classification relates to the Belgian migration history and the presence of large groups from these origins in urban areas. Age (including age squared to control for non-linear effects) and Sex are added too.

In a first step, the model comprises all students $(\mathrm{N}=82,549)$, comparing movers from the domicile of the parental home with non-movers. Persons who died before the first move-out $(\mathrm{N}=19)$ are excluded. The dichotomous dependent captures whether or not an individual has moved out of the parental home, i.e. changed LAU-2 unit (i.e. municipality) to live in an independent household during the period 2001-2010.

In a second step, the analysis is limited to actual movers, comparing those who are attracted to the HE city and those who moved elsewhere. Young adults who moved abroad $(\mathrm{N}=2,382)$ are excluded. To isolate processes of attraction, this migrant population is further reduced to those who were not officially domiciled in the HE city on $1 / 10 / 2001(\mathrm{~N}=56,578)$. Attraction towards the HE location is thus conceptualised as a residential move to the city of $\mathrm{HE}$ (versus not moved to $\mathrm{HE}$ city) since 2001, among mobile students who did not live in this city. This second series of models include all covariates from the first logistic models and are extended with indicators related to distance and context.

Assuming the proximity of the HEI is associated with the likelihood of settling there, the distance between the 2001 residence and the HEI location - DistHEI - is considered (below $15 \mathrm{~km}, 15-30 \mathrm{~km}, 30-50 \mathrm{~km}$ and above $50 \mathrm{~km}$ ). All distances are calculated based on the centroids of the LAU-2 units. Although the Belgian geographical context makes longdistance moves uncommon, if they occur, they tend to concern metropolitan destinations, particularly Brussels. Consequently, the distance moved - DistMoved - is added to the model. It distinguishes similar categories as the previous indicator. 
To account for the structural variability between destination areas, three types of contextual indicators are considered. Based on the related literature, the models include the availability of affordable rental properties (e.g. Helderman, Mulder \& van Ham, 2004; Plantinga, Détang-Dessendre, Hunt \& Piguet, 2013), population density (e.g. Buch et al., 2013; Garasky, 2002) and job availability (Krabel \& Flöther, 2014; Venhorst et al., 2011). All covariates concern cross-sectional information and are based on LAU-2 units (except Brussels, which is considered as the compound region of 19 municipalities). The proportion of affordable rental properties - Rental - is calculated as the share of private rental properties with monthly charges below €750 in the housing market in 2001. Population density - Density - accounts for the number of inhabitants $/ \mathrm{km}^{2}$ in 2001. To allow a meaningful interpretation, it considers an increase per 1000 persons. Job availability - Job - in the destination area is calculated as the number of available jobs per 100 inhabitants between 15 and 64 years of age in $2006^{4}$. Quadratic terms are included for all structural covariates to control for non-linearity.

The third step of the modelling estimates the extent to which cities retain the attracted graduates in the long run using Cox Proportional Hazards modelling (Cox, 1972; BoxSteffensmeier \& Zorn, 2001). The event ('failure') is described as the move out of the municipality of first settlement. The exposure time equals the number of days between leaving the parental home (and thus arrival at the new destination) and the moment the respondent left the first destination (HE city) or 1/1/2010 for those who did not leave the first destination (censored individuals). For clarity reasons and statistical power, analyses are restricted to young adults who settled in their former HE city, extracted from the second series of logistic models $(\mathrm{N}=13,442 ; 54$ censored cases before the earliest event in a stratum are excluded). The baseline model accounts for HEI location, controlled for age. Extended models include all the above-mentioned indicators controlling for socioeconomic and demographic background and for residential and structural variability.

\footnotetext{
${ }^{4}$ Vlaamse Arbeidsrekening, a job ratio based on the annual average of 2006.
} 


\section{Results}

\section{Stayers versus movers}

In 2001, Belgium had 55 municipalities (LAU-2) with an HEI. The 10 most important HE cities (illustrated in Appendix A) together comprise 81.3\% of the 82,530 HE students. About one-third of the students lived in student accommodation, with highest propensities in Leuven, Ghent and Louvain-la-Neuve. A detailed overview of all covariates is provided in Appendix B.

The first series of logistic modelling in table 1 exemplifies the differences between graduates who left the parental home $(85.2 \%)$ during the observation period and those who did not. Model 1 demonstrates that former students from Antwerp, Ghent, Liège and Louvain-la-Neuve are more likely to have moved than the reference group, i.e. Brussels' students. Students from Charleroi, Hasselt and smaller cities conversely, show lower odds of moving. Accounting for the familiarity with the HEI location or the urban environment (model 2), does not result in drastic shifts of the estimated odds ratios (ORs). Characteristics of the parental residence hardly have an influence, contrary to the positive impact of student accommodation. Additional control for socio-economic and sociodemographic characteristics in model 3 results in ORs below unity for Leuven and Hasselt and increased odds of moving for graduates from Louvain-la-Neuve, again compared with Brussels' graduates. A higher socio-economic parental background, being female and having a Belgian origin enhance the odds of leaving the parental home. Logitmodels proved robust when excluding the young adults with unknown parental socioeconomic characteristics.

Table 1. Graduates' likelihood of moving out of the parental home (versus not moving) after 1 October 2001 and before 1 January 2010; N=82,530".

\begin{tabular}{|c|c|c|c|c|c|c|}
\hline & \multicolumn{2}{|c|}{ Model 1} & \multicolumn{2}{|c|}{ Model 2} & \multicolumn{2}{|c|}{ Model 3} \\
\hline & $\operatorname{Exp}(b)$ & $95 \% \mathrm{CI}$ & $\operatorname{Exp}(b)$ & $95 \% \mathrm{CI}$ & $\operatorname{Exp}(b)$ & $95 \% \mathrm{CI}$ \\
\hline \multicolumn{7}{|l|}{ HE City (BCR reference) } \\
\hline Antwerp & $1.13^{* *}$ & $(1.04-1.23)$ & $1.12^{* *}$ & $(1.03-1.22)$ & 1.04 & $(0.95-1.13)$ \\
\hline Ghent & 1.20 ** * & $(1.12-1.29)$ & $1.14^{* *}$ & $(1.06-1.22)$ & 1.06 & $(0.98-1.14)$ \\
\hline Charleroi & $0.85^{*}$ & $(0.73-0.99)$ & 0.91 & $(0.78-1.06)$ & 0.94 & $(0.80-1.10)$ \\
\hline Liège & $1.14^{* *}$ & $(1.05-1.23)$ & $1.12^{* *}$ & $(1.03-1.21)$ & $1.10^{*}$ & $(1.01-1.20)$ \\
\hline Namur & 1.11 & $(0.98-1.26)$ & 1.10 & $(0.97-1.26)$ & 1.06 & $(0.93-1.20)$ \\
\hline Leuven & 1.05 & $(0.98-1.14)$ & $0.92^{*}$ & $(0.85-1.00)$ & $0.85^{* * *}$ & $(0.78-0.92)$ \\
\hline Mons & 0.93 & $(0.84-1.04)$ & 0.94 & $(0.85-1.05)$ & 1.02 & $(0.91-1.14)$ \\
\hline Hasselt & $0.73^{* * *}$ & $(0.65-0.81)$ & $0.76^{* * *}$ & $(0.68-0.85)$ & 0.70 ** * & $(0.62-0.79)$ \\
\hline Louvain-la-Neuve & $1.38 * * *$ & $(1.24-1.54)$ & $1.30 * * *$ & $(1.16-1.45)$ & $1.26^{* * *}$ & $(1.13-1.41)$ \\
\hline Other regional cities & 0.90 * * & $(0.83-0.97)$ & 0.94 & $(0.86-1.02)$ & $0.92^{*}$ & $(0.83-0.99)$ \\
\hline Small cities & $0.84^{* * *}$ & $(0.77-0.90)$ & $0.85^{* * *}$ & $(0.79-0.92)$ & $0.89^{* *}$ & $(0.82-0.97)$ \\
\hline
\end{tabular}

(Continued) 
Table 1. Continued.

\begin{tabular}{|c|c|c|c|c|c|c|}
\hline & \multicolumn{2}{|c|}{ Model 1} & \multicolumn{2}{|c|}{ Model 2} & \multicolumn{2}{|c|}{ Model 3} \\
\hline & $\operatorname{Exp}(b)$ & $95 \% \mathrm{CI}$ & $\operatorname{Exp}(b)$ & $95 \% \mathrm{CI}$ & $\operatorname{Exp}(b)$ & $95 \% \mathrm{CI}$ \\
\hline \multicolumn{7}{|l|}{ StudAcc (No reference) } \\
\hline Yes & & & $1.38 * * *$ & $(1.31-1.45)$ & $1.33^{* * *}$ & $(1.26-1.40)$ \\
\hline \multicolumn{7}{|c|}{ Res01 (Not in HE city reference) } \\
\hline In HE city & & & 1.04 & $(0.97-1.13)$ & 0.97 & $(0.90-1.05)$ \\
\hline \multicolumn{7}{|l|}{ Urban01 (Central city reference) } \\
\hline Agglomeration & & & $1.10^{*}$ & $(1.01-1.19)$ & 1.08 & $(0.99-1.18)$ \\
\hline Banlieue & & & 1.04 & $(0.96-1.12)$ & 0.99 & $(0.91-1.07)$ \\
\hline Commuter zone & & & 0.99 & $(0.92-1.07)$ & 0.94 & $(0.87-1.02)$ \\
\hline Other BE municipality & & & 1.01 & $(0.94-1.08)$ & 0.98 & $(0.90-1.05)$ \\
\hline \multicolumn{7}{|l|}{ EduPar (Low reference) } \\
\hline Intermediate & & & & & $1.09^{* *}$ & $(1.02-1.16)$ \\
\hline High & & & & & $1.08^{*}$ & $(1.02-1.15)$ \\
\hline Unknown attainment & & & & & $1.43^{* * *}$ & $(1.25-1.64)$ \\
\hline \multicolumn{7}{|c|}{ OccupStat (White collar reference) } \\
\hline \multicolumn{3}{|c|}{ Independent - managerial function } & & & $0.90^{* * *}$ & $(0.85-0.94)$ \\
\hline \multicolumn{3}{|c|}{ Blue collar } & & & $0.84^{* * *}$ & $(0.79-0.89)$ \\
\hline \multicolumn{3}{|c|}{ Unemployed - in search for a job } & & & 0.98 & $(0.88-1.10)$ \\
\hline \multicolumn{3}{|c|}{ Unknown occupational status } & & & $0.82^{* *}$ & $(0.76-0.89)$ \\
\hline \multicolumn{7}{|c|}{ HE Type (Professional Bachelors reference) } \\
\hline \multicolumn{3}{|l|}{ Academic Bachelors } & & & $0.93^{*}$ & $(0.87-1.00)$ \\
\hline \multicolumn{3}{|l|}{ Academic Masters } & & & $0.84^{* * *}$ & $(0.79-0.89)$ \\
\hline \multicolumn{3}{|l|}{ Postgraduate Masters } & & & 1.00 & $(0.89-1.12)$ \\
\hline \multicolumn{7}{|l|}{ NatOrig (Belgium reference) } \\
\hline \multicolumn{3}{|l|}{ Turkey - Morocco } & & & $0.45^{* * *}$ & $(0.41-0.50)$ \\
\hline \multicolumn{3}{|l|}{ Southern Europe } & & & $0.67 * * *$ & $(0.61-0.73)$ \\
\hline \multicolumn{3}{|l|}{ Western countries } & & & $0.90^{*}$ & $(0.82-1.00)$ \\
\hline \multicolumn{3}{|l|}{ Non-Western countries } & & & $0.64^{* * *}$ & $(0.57-0.71)$ \\
\hline \multicolumn{7}{|l|}{ Sex (Male reference) } \\
\hline \multicolumn{3}{|l|}{ Female } & & & $2.06^{* * *}$ & $(1.98-2.15)$ \\
\hline \multicolumn{3}{|l|}{ Age } & & & $3.43^{* * *}$ & $(1.99-5.92)$ \\
\hline \multicolumn{3}{|l|}{ Square(Age) } & & & $0.98 * * *$ & $(0.96-0.99)$ \\
\hline Intercept & $5.70 * * *$ & & $5.04^{* * *}$ & & $0.00^{* * *}$ & \\
\hline \multicolumn{3}{|l|}{ Model Chi-Square } & & 7.279 & & 00.264 \\
\hline Df & & & & 17 & & 34 \\
\hline$-2 \mathrm{LL}$ & & 286 & & 30.795 & & 517.810 \\
\hline Nagelkerke R Square & & & & .009 & & 0.048 \\
\hline
\end{tabular}

Notes: Figures give the odds ratios. Significance levels: ${ }^{*}<0.05 ;{ }^{*}<0.01 ;{ }^{*} *<0.001$.

${ }^{2}$ Deceased graduates before moving out of the parental home are excluded. 70,289 graduates have actually left the parental home.

${ }^{\mathrm{b}} \mathrm{HE}$ cities are ranked according to ascending population size.

'Brussels-Capital Region

Sources: Census 1991 and 2001 and National Register 2001-10, authors' calculations

\section{Modelling cities' attractiveness for movers}

To look closer at these residential moves in relation to the HEI location, subsequent analyses apply to home leavers within national boundaries between 2001 and 2010, who had their residence outside the HE city at the start of the observation period (1/10/2001) $(\mathrm{N}=56,678)$. With $23.9 \%$ of these highly educated being attracted to the HE city (table 2), the urban environment of the former place of study is clearly an attractive place to settle. Attractiveness, however, varies markedly between cities. The capital city attracted $36.2 \%$ 
of its non-resident graduate home leavers. Ghent and Antwerp both appear able to keep up, followed by Liège and Leuven. Namur, Charleroi and Mons take intermediate positions, whereas Hasselt and Louvain-la-Neuve have the smallest proportions of graduate in-migrants (11.7\% and 11.2\%), together with other regional and smaller cities.

Table 2. Mobile graduates with an official residence outside the study region in $2001(\mathrm{~N})$, separating those who are attracted to the study region with this first residential move in the period 2001-10 ( $N$ and \%), stratified by the higher education (HE) city attended in 2001.

\begin{tabular}{|c|c|c|c|}
\hline HE city ${ }^{n}$ & $N$ mobile graduates ${ }^{\mathrm{b}}$ & $\begin{array}{l}N \text { attracted mobile } \\
\text { graduates to the HE city }\end{array}$ & $\begin{array}{l}\% \text { attracted mobile } \\
\text { graduates to the HE city }\end{array}$ \\
\hline Brussels-Capital Region & 9,281 & 3,361 & 36.2 \\
\hline Antwerp & 4,784 & 1,536 & 32.1 \\
\hline Ghent & 9,579 & 3,116 & 32.5 \\
\hline Charleroi & 697 & 131 & 18.8 \\
\hline Liège & 5,520 & 1,456 & 26.4 \\
\hline Namur & 1,622 & 339 & 20.9 \\
\hline Leuven & 6,972 & 1,768 & 25.4 \\
\hline Mons & 2,172 & 379 & 17.4 \\
\hline Hasselt & 1,852 & 217 & 11.7 \\
\hline Louvain-la-Neuve & 3,183 & 356 & 11.2 \\
\hline Other regional cities & 5,069 & 551 & 10.9 \\
\hline Smaller cities & 5,847 & 286 & 4.9 \\
\hline Total & 56,578 & $13,496^{(3)}$ & 23.9 \\
\hline \multicolumn{4}{|c|}{$\begin{array}{l}\text { Notes: } \mathrm{HE} \text { cities are ranked according to ascending population size. } \\
\text { "Graduates are defined as mobile when at least one residential move is observed (i.e. leaving the parental home). Here, } \\
\text { only non-resident students in the HE city on } 1 \text { October } 2001 \text { are considered. } \\
\text { 'The attracted former attendant students considered in the subsequent Cox survival analysis. A total of } 54 \text { cases are } \\
\text { dropped from the analyses as these are censored prior to the first event time, thus making no contribution to the } \\
\text { models' estimates. } \\
\text { Sources: Census } 2001 \text { and National Register } 2001-10 \text {, authors' calculations }\end{array}$} \\
\hline
\end{tabular}

To assess and explain cities' attractiveness, logistic regressions are conducted among these mobile young highly educated individuals, predicting the odds of moving to the city in which he/she studied versus moving elsewhere. ORs are presented in table 3.

Model 1 presents the crude effect of the HEI location, with BCR as the reference group. All ORs are lower than unity, indicating that Brussels' graduates are most likely to be attracted towards their HE city. The effect of the HEI location remains fairly similar after including indicators that account for the ability to build up location-specific capital (model 2). Characteristics of previous residence and affiliation with urban settings prove to be important factors for understanding migration towards the HE locality. A stay in student accommodation and living close to the HEI or the urban environment in general, greatly enhance the likelihood of graduates being attracted to the HE city. Controlling for socio-economic and demographic characteristics (model 3) results in highly similar odds 
for HE city and residential characteristics. Results indicate an educational differential; those with academic degrees show higher odds of being attracted to live in the city in which they studied than their counterparts with a bachelor degree. Socio-economic parental characteristics behave similarly: graduates having a parent with a tertiary degree or being employed in white-collar jobs exhibit higher ORs than those having low educated parents and those having blue-collar or self-employed fathers (or mothers in the case of a single-mother household). All minority ethnic groups show evidence of intensified likelihood of attraction towards the HE city compared with their Belgian-origin counterparts. Particularly, being of Turkish or Moroccan origin has a favourable effect on the HEI location's attractiveness. Age was found irrelevant, whereas female graduates are less likely than males to settle in the $\mathrm{HE}$ city during this first move out of the parental home.

Including an additional control for the distance moved (model 4) does not generate notable shifts in the ORs, except for Ghent. An inverse 'U'-shaped relation is observed between the tendency of being attracted towards the HEI location and the distance over which one has moved.

Incorporation of three contextual variables (affordable rental properties, population density and job availability) has a considerable impact on the HE location's attractiveness (model 5). Relatively small cities, such as Namur and Mons, become more attractive than the BCR, the ORs being half to twice as high as in the capital. The attractiveness of Ghent and Charleroi no longer differs from that of Brussels. The ORs of Antwerp and Leuven drop, those of Liège and Hasselt ameliorate slightly relative to BCR. Accounting for interurban divergence considerably affects the importance of some background characteristics. Overall, socio-economic and demographic indicators as well as the distance moved lose significance or magnitude. Importantly, however, ties with the HEI location or urban environment remain of great importance once inter-city differences are considered. Concerning the structural variability, an inverse U-shape is observed for population density, indicating how the relation with urban attractiveness turns negative once a certain density threshold (i.e. 5,640 inhabitants $/ \mathrm{km}^{2}$ ) is exceeded. Both the availability of affordable rental dwellings and of jobs appears to trace a fairly weak negative relationship with the odds of graduate attraction to the city of HE. 
Table 3. Likelihood of settlement in the study region (versus elsewhere) for mobile graduates who originate from outside the city of higher education (HE), 2001-10; $\mathrm{N}=56,578$

\begin{tabular}{|c|c|c|c|c|c|c|c|c|c|c|}
\hline & \multicolumn{2}{|c|}{ Model 1} & \multicolumn{2}{|r|}{ Model 2} & \multicolumn{2}{|c|}{ Model 3} & \multicolumn{2}{|r|}{ Model 4} & \multicolumn{2}{|c|}{ Model 5} \\
\hline & $\operatorname{Exp}(b)$ & $95 \% \mathrm{CI}$ & $\operatorname{Exp}(b)$ & $95 \% \mathrm{CI}$ & $\operatorname{Exp}(b)$ & $95 \%$ CI & $\operatorname{Exp}(b)$ & $95 \% \mathrm{CI}$ & $\operatorname{Exp}(b)$ & $95 \% \mathrm{CI}$ \\
\hline \multicolumn{11}{|l|}{ HE City (BCR reference) } \\
\hline Antwerp & $0.83^{* * *}$ & $(0.77-0.90)$ & $0.70^{* * *}$ & $(0.65-0.75)$ & $0.78 * * *$ & $(0.72-0.84)$ & $0.86^{* *}$ & $(0.79-0.94)$ & $0.57 * * *$ & $(0.51-0.64)$ \\
\hline Ghent & $0.85^{* * *}$ & $(0.80-0.90)$ & 0.81 ** * & $(0.76-0.86)$ & 0.87 ** * & $(0.82-0.93)$ & 0.98 & $(0.91-1.05)$ & 1.03 & $(0.93-1.12)$ \\
\hline Charleroi & $0.41 * * *$ & $(0.34-0.50)$ & $0.37^{* * *}$ & $(0.31-0.46)$ & $0.42^{* * *}$ & $(0.34-0.51)$ & 0.37 * * & $(0.30-0.46)$ & 1.21 & $(0.93-1.58)$ \\
\hline Liège & $0.63^{* * *}$ & $(0.59-0.68)$ & $0.57^{* * *}$ & $(0.52-0.61)$ & $0.59^{* * *}$ & $(0.55-0.64)$ & $0.59^{* * *}$ & $(0.54-0.64)$ & $0.72^{* *}$ & $(0.63-0.81)$ \\
\hline Namur & 0.47 ** & $(0.41-0.53)$ & $0.51^{* * *}$ & $(0.45-0.58)$ & $0.58 * * *$ & $(0.51-0.66)$ & $0.52 * * *$ & $(0.45-0.60)$ & $1.71^{* * *}$ & $(1.44-2.03)$ \\
\hline Leuven & 0.60 *** & $(0.56-0.64)$ & $0.47^{* * *}$ & $(0.44-0.51)$ & 0.47 ** * & $(0.43-0.50)$ & $0.47 * * *$ & $(0.44-0.51)$ & $0.28 * * *$ & $(0.25-0.32)$ \\
\hline Mons & 0.37 ** * & $(0.33-0.42)$ & $0.39^{* * *}$ & $(0.34-0.44)$ & $0.40^{* * *}$ & $(0.35-0.45)$ & $0.39^{* * *}$ & $(0.34-0.45)$ & $2.06^{* * *}$ & $(1.75-2.42)$ \\
\hline Hasselt & $0.23^{* * *}$ & $(0.21-0.27)$ & $0.24^{* * *}$ & $(0.21-0.36)$ & 0.30 ** * & $(0.26-0.36)$ & 0.30 ** * & $(0.25-0.35)$ & 0.51 ** * & $(0.41-0.63)$ \\
\hline Louvain-la-Neuve & $0.22 * * *$ & $(0.20-0.25)$ & $0.19^{* * *}$ & $(0.17-0.22)$ & 0.17 * * & $(0.15-0.19)$ & $0.13^{* * *}$ & $(0.11-0.15)$ & $0.13 * * *$ & $(0.11-0.15)$ \\
\hline Other regional cities & $0.22 * * *$ & $(0.20-0.24)$ & $0.21 * * *$ & $(0.19-0.24)$ & $0.27 * * *$ & $(0.24-0.30)$ & $0.26 * * *$ & $(0.24-0.29)$ & $0.33 * * *$ & $(0.29-0.38)$ \\
\hline Small cities & $0.09^{* * *}$ & $(0.08-0.10)$ & $0.09^{* * *}$ & $(0.08-0.10)$ & $0.10^{* * *}$ & $(0.09-0.12)$ & $0.08^{* * *}$ & $(0.07-0.10)$ & $0.09^{* * *}$ & $(0.08-0.11)$ \\
\hline \multicolumn{11}{|l|}{ StudAcc (No reference) } \\
\hline Yes & & & $2.68 * * *$ & $(2.55-2.82)$ & $2.56^{* * *}$ & $(2.43-2.69)$ & $2.21^{* * *}$ & $(2.09-2.33)$ & $2.09^{* * *}$ & $(1.96-2.23)$ \\
\hline \multicolumn{11}{|l|}{ DistHEI ( $<15 \mathrm{~km}$ reference) } \\
\hline $15-29 \mathrm{~km}$ & & & 0.47 ** * & $(0.44-0.50)$ & $0.46^{* * *}$ & $(0.43-0.49)$ & $0.28 * * *$ & $(0.26-0.30)$ & 0.21 * * & $(0.19-0.23)$ \\
\hline $30-49 \mathrm{~km}$ & & & $0.41^{* * *}$ & $(0.38-0.44)$ & $0.40^{* * *}$ & $(0.37-0.43)$ & $0.18^{* * *}$ & $(0.17-0.20)$ & $0.15^{* * *}$ & $(0.13-0.16)$ \\
\hline $250 \mathrm{~km}$ & & & $0.38^{* * *}$ & $(0.35-0.41)$ & 0.36 ** & $(0.33-0.39)$ & $0.15^{* * *}$ & $(0.13-0.16)$ & 0.13 ** * & $(0.12-0.15)$ \\
\hline \multicolumn{11}{|c|}{ Urban01 (Central city reference) } \\
\hline Agglomeration & & & $1.20^{* * *}$ & $(1.10-1.31)$ & 1.22 *** & $(1.12-1,34)$ & $1.26^{* * *}$ & $(1.14-1.39)$ & $1.17^{\text {* * }}$ & $(1.05-1.31)$ \\
\hline Banlieue & & & $1.24^{* * *}$ & $(1.14-1.35)$ & $1.30 * * *$ & $(1.20-1.41)$ & $1.19 * * *$ & $(1.09-1.30)$ & $1.48 * * *$ & $(1.34-1.64)$ \\
\hline Commuterzone & & & $1.08^{*}$ & $(1.00-1.17)$ & $1.17^{* * *}$ & $(1.08-1.26)$ & 1.01 & $(0.93-1.10)$ & $1.66^{* * *}$ & $(1.50-1.83)$ \\
\hline Other BE municipalitie: & & & 1.07 & $(0.99-1.16)$ & $1.18^{* * *}$ & $(1.09-1.28)$ & 1.03 & $(0.94-1.11)$ & $1.74^{* * *}$ & $(1.58-1.92)$ \\
\hline \multicolumn{11}{|l|}{ EduPar (Low reference) } \\
\hline High & & & & & $1.33^{* * *}$ & $(1.24-1.43)$ & $1.28 * * *$ & $(1.18-1.38)$ & 0.96 & $(0.87-1.07)$ \\
\hline Intermediate & & & & & 1.05 & $(0.98-1.13)$ & 1.06 & $(0.98-1.15)$ & 0.98 & $(0.89-1.08)$ \\
\hline Unknown attainment & & & & & $1.45^{* * *}$ & $(1.31-1.60)$ & 1.41 ** & $(1.27-1.57)$ & $1.16^{*}$ & $(1.01-1.32)$ \\
\hline \multicolumn{11}{|c|}{ OccupStat (White collar reference) } \\
\hline Independent - manageri & function & & & & $0.91 * * *$ & $(0.86-0.96)$ & $0.91^{* *}$ & $(0.86-0.97)$ & $0.88 * * *$ & $(0.82-0.95)$ \\
\hline Blue collar & & & & & $0.81 * * *$ & $(0.75-0.87)$ & $0.83^{* * *}$ & $(0.76-0.90)$ & $0.90^{*}$ & $(0.81-0.99)$ \\
\hline Unemployed - in search & or job & & & & $1.17^{*}$ & $(1.03-1.33)$ & $1.16^{*}$ & $(1.01-1.33)$ & 1.11 & $(0.94-1.31)$ \\
\hline Unknown occupational & tus & & & & $0.88^{* *}$ & $(0.81-0.95)$ & $0.89^{* *}$ & $(0.81-0.96)$ & $0.87^{*}$ * & $(0.79-0.97)$ \\
\hline
\end{tabular}


Table 3. Continued.

\begin{tabular}{|c|c|c|c|c|c|c|c|c|}
\hline & Model 1 & Model 2 & \multicolumn{2}{|r|}{ Model 3} & \multicolumn{2}{|r|}{ Model 4} & \multicolumn{2}{|r|}{ Model 5} \\
\hline & $95 \% \mathrm{CI}$ & $95 \%$ CI & $\operatorname{Exp}(b)$ & $95 \% \mathrm{CI}$ & $\operatorname{Exp}(b)$ & $95 \% \mathrm{CI}$ & $\operatorname{Exp}(b)$ & $95 \% \mathrm{CI}$ \\
\hline \multicolumn{9}{|c|}{ HE Type (Professional Bachelors reference) } \\
\hline Academic Bachelors & & & $1.09^{*}$ & $(1.02-1.17)$ & 1.04 & $(0.97-1.12)$ & 0.94 & $(0.86-1.03)$ \\
\hline Academic Masters & & & $1.25^{* * *}$ & $(1.18-1.33)$ & $1.13^{* * *}$ & $(1.06-1.20)$ & 0.97 & $(0.90-1.05)$ \\
\hline Postgraduate Masters & & & 0.97 & $(0.88-1.07)$ & $0.90^{*}$ & $(0.81-1.00)$ & $0.67 * * *$ & $(0.59-0.76)$ \\
\hline \multicolumn{9}{|l|}{ NatOrig (Belgium reference) } \\
\hline Turkey - Morocco & & & $1.73^{* * *}$ & $(1.45-2.06)$ & $1.77^{\text {** * }}$ & $(1.47-2.13)$ & 1.04 & $(0.84-1.29)$ \\
\hline Southern Europe & & & $1.31^{* * *}$ & $(1.18-1.46)$ & 1.31 ** * & $(1.17-1.47)$ & $1.26^{* *}$ & $(1.10-1.45)$ \\
\hline Western countries & & & $1.33^{* * *}$ & $(1.20-1.47)$ & 1.30 ** * & $(1.16-1.44)$ & $1.23^{* *}$ & $(1.08-1.41)$ \\
\hline Non-Western countries & & & $1.48^{* * *}$ & $(1.29-1.69)$ & $1.43^{* * *}$ & $(1.24-1.65)$ & 1.13 & $(0.96-1.34)$ \\
\hline Age & & & 1.07 & $(0.62-1.85)$ & 1.14 & $(0.64-2.04)$ & $0.45^{*}$ & $(0.22-0.92)$ \\
\hline Square(Age) & & & 1.00 & $(0.99-1.01)$ & 1.00 & $(0.99-1.01)$ & $1.02^{*}$ & $(1.00-1.04)$ \\
\hline \multicolumn{9}{|l|}{ Sex (Male reference) } \\
\hline Female & & & $0.87^{* * *}$ & $(0.83-0.90)$ & $0.89^{* * *}$ & $(0.85-0.93)$ & 1.03 & $(0.97-1.09)$ \\
\hline \multicolumn{9}{|l|}{ DistMoved ( $<15 \mathrm{~km}$ reference) } \\
\hline $15-29 \mathrm{~km}$ & & & & & 5.17 ** * & $(4.85-5.51)$ & $3.52^{* * *}$ & $(3.25-3.85)$ \\
\hline $30-49 \mathrm{~km}$ & & & & & $8.52^{* * *}$ & $(7.91-9.17)$ & $4.15^{* * *}$ & $(3.80-4.59)$ \\
\hline$\geq 50 \mathrm{~km}$ & & & & & $7.63^{* * *}$ & $(7.08-8.22)$ & $3.09^{* * *}$ & $(2.83-3.49)$ \\
\hline Rental & & & & & & & $0.97^{* *}$ & $(0.94-0.98)$ \\
\hline Square(Rental) & & & & & & & 1.00 & $(1.00-1.01)$ \\
\hline Job & & & & & & & $1.05^{* * *}$ & $(1.05-1.05)$ \\
\hline Square(Job) & & & & & & & $0.86^{* * *}$ & $(0.83-0.89)$ \\
\hline Density & & & & & & & $6.84^{* * *}$ & $(6.35-7.37)$ \\
\hline Square(Density) & & & & & & & $0.84^{* * *}$ & $(0.83-0.85)$ \\
\hline Intercept & $0.57^{* * *}$ & $0.67^{* * *}$ & 0.08 & & 0.04 & & 5.76 & \\
\hline Model Chi-Square & 3974.295 & 6123.387 & & 6820.754 & & 12831.931 & & 8028.622 \\
\hline Df & 11 & 19 & & 36 & & 39 & & 45 \\
\hline$-2 \mathrm{LL}$ & 58192.342 & 56043.250 & & 55345.883 & & 49334.71 & & 33978.83 \\
\hline Nagelkerke R Square & 0.102 & 0.154 & & 0.170 & & 0.304 & & 0.589 \\
\hline
\end{tabular}

Notes: Figures give the odds ratios. Significance levels: ${ }^{*}<0.05 ;{ }^{*} *<0.01 ;{ }^{* * *}<0.001$

${ }^{2} \mathrm{HE}$ cities are ranked according to ascending population size.

" Number of residents per $\mathrm{km}^{2}$; rescaled so that a 1 unit increase equals a surplus of 1000 residents/sq.km.

Sources: Census 1991 and 2001 and National Register 2001-10, authors' calculations 
In sum, these regressions show that the position of Brussels as the capital of Belgium does not necessarily imply a higher attractiveness among its recent graduates when cities' structural characteristics are held comparable. The results are in line with an economic narrative. The opportunity to acquire familiarity with the study region together with individual characteristics, however, remains important in graduates' residential behaviour toward the HE locality. The subsequent part of this paper considers this further by investigating differences between cities of $\mathrm{HE}$ in the retention of graduates.

\section{Who Stays?}

The analyses in this section are restricted to the 13,442 highly educated who actually moved to their HEI location between 2001 and 2010. During the observation period, which starts when leaving the parental home and ends on 1/1/2010, 6,992 graduates left the city again and 6,450 were right-censored. The cumulative survival for graduates is calculated as the percentage of graduates still in the city of $\mathrm{HE}$ at the end of each interval in the observation period.

Plotting the HE cities' survival curves for the basic model sheds light on the retention capacity of HE localities (figure 1(a), model 1). For clarity, graphs only highlight the most distinct curves. Survival curves in colour are provided in in Figures C1 and C2 in Appendix C. In the Brussels capital and Louvain-la-Neuve, the latter characterised by a large student population, cumulative survival rates after first settlement quickly drop below 50\% (respectively solid and dashed bold lines at the bottom). Antwerp and Ghent on the contrary are able to retain a larger share of their graduates over time (respectively solid and dashed black lines at the top). All other cities take intermediate positions in terms of remaining attractive for the settled former students (grey).

Overall, the explanatory power of individual, residential and structural indicators in relation to differential graduate retention of $\mathrm{HE}$ cities is rather modest: the characteristics that proved important for the attractiveness of $\mathrm{HE}$ locations appear to lose their significance for predicting retention over time. The cumulative survival for the different $\mathrm{HE}$ locations after statistical control for socio-demographic and residential features (model 2, not shown) reveals a highly similar pattern. The additional control for inter-urban divergence (figure 1(b), final model) illustrates that, once structural variability is accounted for, cumulative survival rates for BCR drop considerably. This diminution is not observed 
for the other HE cities. As the second largest city, Antwerp, performs quite well in retaining its students for a long period of time. Ghent remains in its leading position, yet less pronounced. In line with the particularity of a typical 'student city', Louvain-la-Neuve does not manage to retain its graduates in the long term.

Figure 1. Cumulative survival function for attracted graduate migrants $(\mathrm{N}=13,442)$, by city of higher education (HE) in 2001: (a) model 1 includes HE institution (HEI) location and controls for age; and (b) the final model includes HEI location and controls for demographic, socio-economic, residential and contextual characteristics.
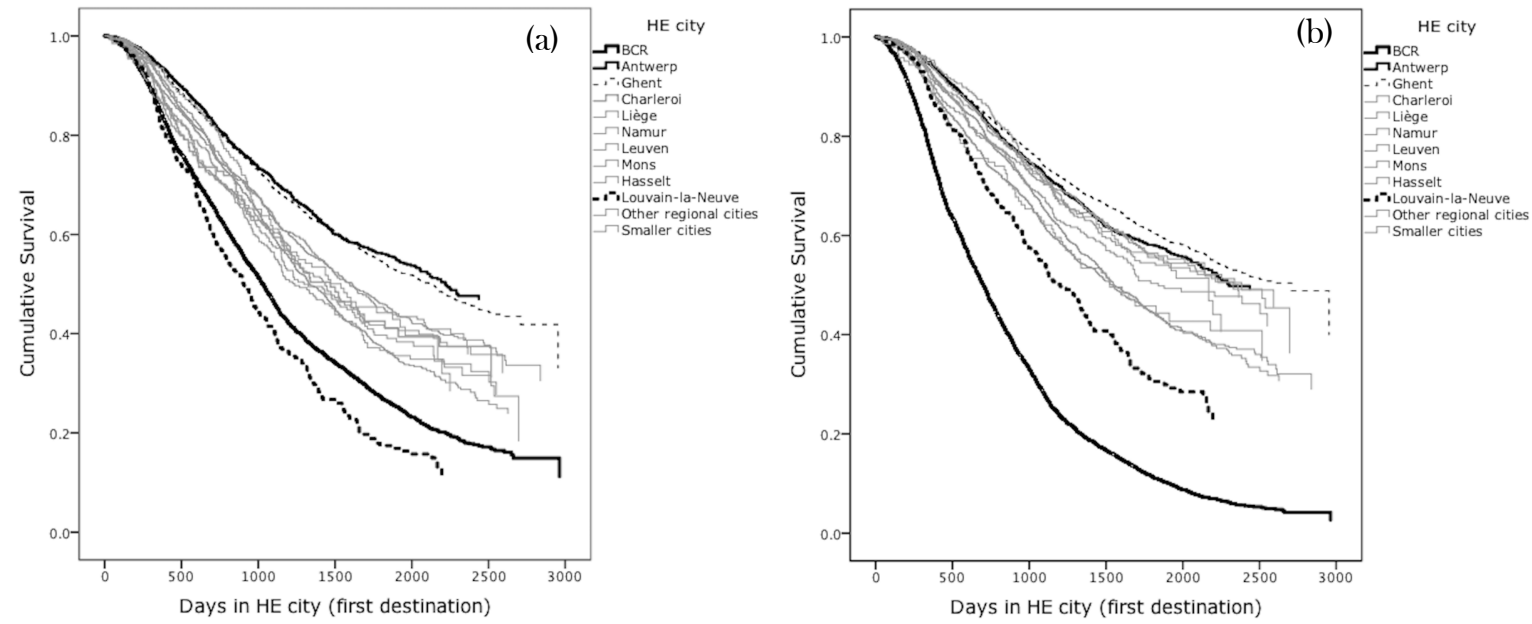

Sources: Census 1991 and 2001 and National Register 2001-10, authors' calculations

In sum, these findings reveal that cities differ in their ability to attract and retain their locally produced graduates. During the observation period 2001-2010, Ghent, and, to a somewhat lesser extent, Antwerp, retain the highest share of their graduates who made a residential move into the city.

\section{Discussion and conclusions}

Human capital research has increasingly devoted attention to individual and contextual drivers of skilled young adults' residential behaviour enhancing our comprehension of economic determinants of graduate migration. However, extant studies too often overlook the potential importance of non-economic characteristics of places. One study that attempts to broaden the economic approach to skilled migration is Ciriaci's (2014) paper on the relevance of universities' research and teaching quality for the residential behaviour of the 
student population in their early professional career. However, rather than only institutional characteristics, this study argues that location-specific capital related to the study region in general determines migration patterns of graduates in the short and long term after their graduation.

The present study reveals some noteworthy results. First, analyses demonstrated high levels of residential mobility among the skilled (85.2\%) who tend to settle either within the close environment of their parental home or in larger urban areas. For about one-third of the graduate home leavers, the urban locality was related to the location and process of $\mathrm{HE}$ knowledge acquisition, suggesting the role of regional familiarity in their residential behaviour. At first sight, the BCR appeared the most attractive destination compared with any other HE city in Belgium. Assuming that graduates make a comparative assessment of costs and benefits related to a move in order to obtain a suitable job, its attractiveness to high-skilled people is rather self-evident as expected income is higher (Borjas et al., 1992; Statistics Belgium, 2011). Long-distance moves being observed only in the case of Brussels supports this argument. Of course, only the BCR has both French and Flemish universities and colleges on its territory and thus a larger catchment for its in-migrants than other cities; Regional boundaries, cultural differences and language barriers seem powerful incentives for young adults (not) to migrate in the Belgian case.

Second, the BCR's attractiveness seems at least partly indebted to its capital function and international character rather than being the former HE city. Once structural betweencity variability is accounted for (affordable rental housing, population density and job availability), smaller cities such as Namur and Mons exhibited higher rates of in-migration of their graduates than the BCR. Cox modelling demonstrated how these smaller cities better manage to retain their graduates in the decade after migration than BCR. The idea that a large city, ceteris paribus, is most attractive (Buch et al., 2013) does not hold. Of course, the availability of facilities, services, amenities, transportation and a vibrant social life are plausible explanations for a city's appeal (Howley, 2009). Yet, cities'sustainability could be at odds with cities' liveability, as the latter requires functions and populations to be dispersed at lower densities (Neuman, 2005). The inverse 'U'-shaped effect of population density in our logit models suggests that once a certain threshold has been crossed, the attraction of a city, i.e. Brussels and, to a lesser extent, Antwerp, could be reduced owing to an inferior (perceived) liveability compared with smaller cities, such as Namur, Mons, 
Liège or Ghent. The high price of living space and dwellings within the capital, negatively adds up to its (perceived) attractiveness. So despite the job opportunities in the labour market that demand increasingly high requirements in terms of skills (Van Hamme, Wertz \& Biot, 2011), the BCR seemingly is unable to overcome sensed differences in quality of life compared with suburban or other areas.

Third, parental capital can facilitate a move, parental resources off-setting a potential lack of financial means, especially at the very beginning of one's professional career. The higher attraction of ethnic minority origin groups to cities of HE study could indicate how the lack of economic parental resources (especially among Turks and Moroccans) is counterbalanced by the acquired location-specific capital that is built up through residencebased experiences.

Overall, this paper's findings support the idea that 'location-specific insider advantages' (Fischer \& Malmberg, 2001) or 'location-specific human capital' (Haapanen \& Tervo, 2012) acquired during HE can enhance the appeal of a city after graduation. However, locationspecific advantages appear likely to become less useful once graduates have built up economic capital through the expansion of a professional career and an increasing wage. This phenomenon was most pronounced in Brussels, which, as discussed above, was relatively less successful at retaining graduates over the long term. Of course, the replenishment of graduates who leave the cities with more recent graduates could secure cities' sustainability in terms of highly skilled population, especially in the Brussels' case where absolute numbers of HE graduates are highest. Importantly, however, the earnings of graduates at the start of their professional career are lower than later on and so are their tax contributions. Furthermore, the replenishment with non-local graduates, i.e. the exchange of graduates between HEI locations in Belgium, is negligible. In line with the importance of regional familiarity for graduate residential choices (Venhorst, 2013), nonlocally produced graduates tend to settle in the close environment of their former HEI or their family but rarely in another HE city.

The apparent relative success of smaller cities in attracting and retaining graduates may be due to the fact of graduates having found jobs that match their profile. Our data do not provide information on job status or location after graduation, and this is one of the limitations of the study. As such, models cannot account for the type of job, income or other individual labour market-related characteristics that affect graduate migration. Given 
the considerable divergence between conditions and opportunities offered by labour markets in each of the $\mathrm{HE}$ cities, the incompatibility of $\mathrm{HE}$ degrees and low-skilled jobs plausibly hinders residential attractiveness. Commuters were not traceable in the graduate population as a consequence of the selection criteria used. All things considered, the interpretation of our findings in light of the recently observed urban fiscal shortages and social polarisation is rather conservative, particularly in the case of Brussels where absolute numbers of commuters are very high. Thus, we may well underestimate the financial burden non-resident workers place on the city's infrastructure, and the relative advantage of smaller cities in terms of attraction and retention of graduates.

Ideally, multivariate models would include a wide array of location-specific factors. While it is almost impossible to integrate an exhaustive list of all kinds of amenities, a database with such extensive covariates is not (yet) available but would be a useful development for further research. Indeed, to grasp fully the potential ability of (HE) cities to attract and retain the most skilled, further study of the location-specific incentives shaping graduate migration is needed. Acquaintance with or knowledge about the available housing stock, availability of childcare and primary schools, cultural amenities, language or regional boundaries, social networks and perceived environmental quality constitute location-specific factors of future research interest. In probing the role that HE locations hold in graduate migration, future studies should particularly aim at better disentangling (1) the location-specific factors bound to a place, to local communities or to the life course, that attract people; and (2) social, cultural and ethnic variability, especially within the context of increasing diversity and social polarization in many Western urban areas.

Local authorities need to invest further in enhancing central cities' attractiveness and should implement policies to meet the residential preferences of young adults in the long run, as they accumulate financial resources and move through the life course. Only in safeguarding the value of location-specific capital in all stages of life, will a higher proportion of people who studied in the city contribute to local tax revenue and to the long-term sustainability and liveability of cities.

\section{Acknowledgments}

The authors thank the anonymous referees for their useful suggestions. 


\section{Funding}

This work was supported by the Research Foundation Flanders (Aspirant Fonds Wetenschappelijk Onderzoek - Vlaanderen).

\section{Disclosure statement}

The authors have no potential conflict of interest to declare.

\section{References}

Baryla, E., \& Dotterweich, D. (2001). Student Migration: Do Significant Factors Vary by Region? Education Economics, 9, 269-280. doi: 10.1080/09645290110086135

Biagi, B., Faggian, A., \& McCann, P. (2011). Long and short distance migration in Italy: the role of economic, social and environmental characteristics. Spatial Economic Analysis, 6, 111-131. doi:10.1080/17421772.2010.540035

Blomquist, G. C., Berger, M. C., \& Hoehn, J. P. (1988). New estimates of quality of life in urban areas. American Economic Review, 78, 89-107. Retrieved from http://www.jstor.org/stable/1814700

Böckerman, P., \& Haapanen, M. (2013). The effect of polytechnic reform on migration. Journal of Population Economics, 26, 593-617. doi: 10.1007/s00148-012-0454-4

Borjas, G. J., Bronars, S. G., \& Trejo, S. J. (1992). Self-selection and internal migration in the United States. Journal of Urban Economics, 32, 159-185. Retrieved from http://www.sciencedirect.com/science/journal/00941190/32/2?sdc=1

Box-Steffensmeier, J., \& Zorn, C. (2001). Duration Models and Proportional Hazards in Political Science. American Journal of Political Science, 45, 972-988. doi: $10.2307 / 2669335$

Buch, T., Hamann, S., Niebuhr, A., \& Rossen, A. (2013). What makes cities attractive? The determinants of urban labour migration in Germany. Urban Studies, 51, 19601978. doi: 10.1177/0042098013499796

Butler, T., \& Hamnett, C. (2007). The geography of education: Introduction. Urban Studies, 44, 1161-1174. doi: 10.1080/00420980701329174

Ciriaci, D. (2014). Does University Quality Influence the Interregional Mobility of Students and Graduates? The Case of Italy. Regional Studies, 48, 1592-1608. doi:10.1080/00343404.2013.821569 
Coniglio, N. D., \& Prota, F. (2008). Human capital accumulation and migration in a peripheral EU region: the case of Basilicata. Papers in Regional Science, 87, 77-95. doi: 10.1111/j.1435-5957.2007.00149.x

Cox, D. (1972). Regression Models and Life Tables. Journal of the Royal Statistical Society. Serial B (Methodological), 34, 187-220. Retrieved from http://www.jstor.org/stable/2985181

Davanzo, J. (1983). Repeat migration in the United States: Who moves back and who moves on? The Review of Economics and Statistics, 65, 552-559. Retrieved from http://www.jstor.org/stable/1935923

Delisle, F., \& Shearmur, R. (2010). Where does all the talent flow? Migration of young graduates and nongraduates, Canada 1996-2001. The Canadian Geographer, 54, 305323. doi: 10.1111/j.1541-0064.2009.00276.x

Devogelaer, D. (2004). Interne migraties in België: Wie, waarom en naar welke gemeente? En waarom niet naar steden? (Working Paper No. 8-(4)). Brussels: Federaal Planbureau.

Dotti, N. F., Fratesi, U., Lenzi, C., \& Percoco, M. (2013). Local Labour Markets and the Interregional Mobility of Italian University Students. Spatial Economic Analysis, 8, 443-468. doi: 10.1080/17421772.2013.833342

Faggian, A., Comunian, R., Jewell, S., \& Kelly, U. (2013). Bohemian graduates in the UK: Disciplines and location determinants of creative careers. Regional Studies, 47, 183200. doi: 10.1080/00343404.2012.665990

Faggian, A., \& McCann, P. (2009). Universities, agglomerations and graduate human capital mobility. Tijdschrift voor Economische en Sociale Geografie, 100, 210-223. doi: 10.1111/j.1467-9663.2009.00530.x

Faggian, A., McCann, P., \& Sheppard, S. (2006). An analysis of ethnic differences in UK graduate migration behaviour. The Annals of Regional Science, 40, 461-471. doi: 10.1007/s00168-006-0061-y

Faggian, A., McCann, P., \& Sheppard, S. (2007). Some evidence that women are more mobile than men: Gender differences in U.K. graduate migration behaviour. Journal of Regional Science, 47, 517-539. doi: 10.1111/j.1467-9787.2007.00518.x

Feijten, P., \& Mulder, C. H. (2002). The timing of household events and housing events in the Netherlands: A longitudinal perspective. Housing Studies, 17, 773-792. doi: 
$10.1080 / 026730302200000980$

Fischer, P. A., \& Malmberg, G. (2001). Settled people don't move: On life course and (im-)mobility in Sweden. International Journal of Population Geography, 7, 357-371. doi: 10.1002/ijpg.230

Florida, R. (2002). Bohemia and economic geography. Journal of Economic Geography, 2, 55-71. doi: 10.1093/jeg/2.1.55

Fratesi, U. (2014). Editorial: The Mobility of High-Skilled Workers - Causes and Consequences. Regional Studies, 48, 1587-1591. doi: $10.1080 / 00343404.2014 .955689$

Garasky, S. (2002). Where are they going? A comparison of urban and rural youths' locational choices after leaving the parental home. Social Science Research, 31, 409431. doi: 10.1016/S0049-089X(02)00007-8

Graves, P. (1980). Migration and climate. Journal of Regional Science, 20, 227-237. doi: 10.1111/j.1467-9787.1980.tb00641.x

Haapanen, M., \& Tervo, H. (2012). Migration of the highly educated: Evidence from residence spells of university graduates. Journal of Regional Science, 52, 587-605. doi: 10.1111/j.1467-9787.2011.00745.x

Helderman, A. C., Mulder, C. H., \& van Ham, M. (2004). The changing effect of home ownership on residential mobility in the Netherlands, 1980-98. Housing Studies, 19, 601-616. doi: 10.1080/0267303042000221981

Hoare, A., \& Corver, M. (2010). The regional geography of new young graduate labour in the UK. Regional Studies, 44, 477-494. doi: 10.1080/00343400902736543

Howley, P. (2009). Attitudes towards compact city living: Towards a greater understanding of residential behaviour. Land Use Policy, 26, 792-798. doi: 10.1016/j.landusepol.2008.10.004

Kley, S. A., \& Mulder, C. H. (2010). Considering, planning, and realizing migration in early adulthood. The influence of life-course events and perceived opportunities on leaving the city in Germany. Journal of Housing and the Built Environment, 25, 7394. doi: 10.1007/s10901-009-9167-8

Krabel, S., \& Flöther, C. (2014). Here today, gone tomorrow? Regional labour mobility of German university graduates. Regional Studies, 48, 1609-1627. doi: $10.1080 / 00343404.2012 .739282$ 
Kulu, H., \& Milewski, N. (2007). Family change and migration in the life course. Demographic Research, 17, 567-590. doi: 10.4054/DemRes.2007.17.19

Neuman, M. (2005). The Compact City Fallacy. Journal of Planning and Research, 25, 11-26. doi: 10.1177/0739456X04270466

Plantinga, A. J., Détang-Dessendre, C., Hunt, G. L., \& Piguet, V. (2013). Housing prices and inter-urban migration. Regional Science and Urban Economics, 43, 296-306. doi: 10.1016/j.regsciurbeco.2012.07.009

Poelmans, L., \& Van Rompaey, A. (2009). Detecting and modelling spatial patterns of urban sprawl in highly fragmented areas: A case study in the Flanders-Brussels region. Landscape and Urban Planning, 93, 10-19. doi: 10.1016/j.landurbplan.2009.05.018

Statistics Belgium (2011). Different income evolutions in the different regions. Brussels: Statistics Belgium.

Van Hamme, G., Wertz, I., \& Biot, V. (2011). Economic growth devoid of social progress: the situation in Brussels. Brussels Studies, 48, 1-18. Retrieved from http://www.briobrussel.be/assets/andere\%20publicaties/en_135_brus48en.pdf

Van Hecke, E., Halleux, J., Decroly, J., \& Mérenne-Schoumaker, B. (2009). Woonkernen en Stadsgewesten in een Verstedelijkt België (Monograph No. 9: Verstedelijking). Brussels: FOD Economie, K.M.O., Middenstand en Energie Algemene Directie Statistiek en Economische Informatie.

Venhorst, V. (2013). Graduate migration and regional familiarity. Tijdschrift voor Economische en Sociale Geografie, 104, 109-119. doi: 10.1111/tesg.12000

Venhorst, V., Van Dijk, J., \& Van Wissen, L. (2010). Do the best graduates leave the peripheral areas of the Netherlands? Tijdschrift voor Economische en Sociale Geografie, 101, 521-537. doi: 10.1111/j.1467-9663.2010.00629.x

Venhorst, V., Van Dijk, J., \& Van Wissen, L. (2011). An analysis of trends in spatial mobility of Dutch graduates. Spatial Economic Analysis, 6, 57-82. doi: $10.1080 / 17421772.2010 .540033$

Verhetsel, A., Thomas, I., \& Beelen, M. (2010). Commuting in Belgian metropolitan areas: The power of the Alonso-Muth model. Journal of Transport and Land Use, 2, 109-131. doi: 10.5198/jtlu.v2i3.19

Whisler, R. L., Waldorf, B. S., Mulligan, G. F., \& Plane, D. A. (2008). Quality of life and the migration of the college-educated: A life-course approach. Growth and Change, 
39, 58-94. doi: 10.1111/j.1468-2257.2007.00405.x 


\section{Appendix A. Regions and higher education cities in Belgium}

Figure A1. Administrative regions and largest higher education cities in Belgium

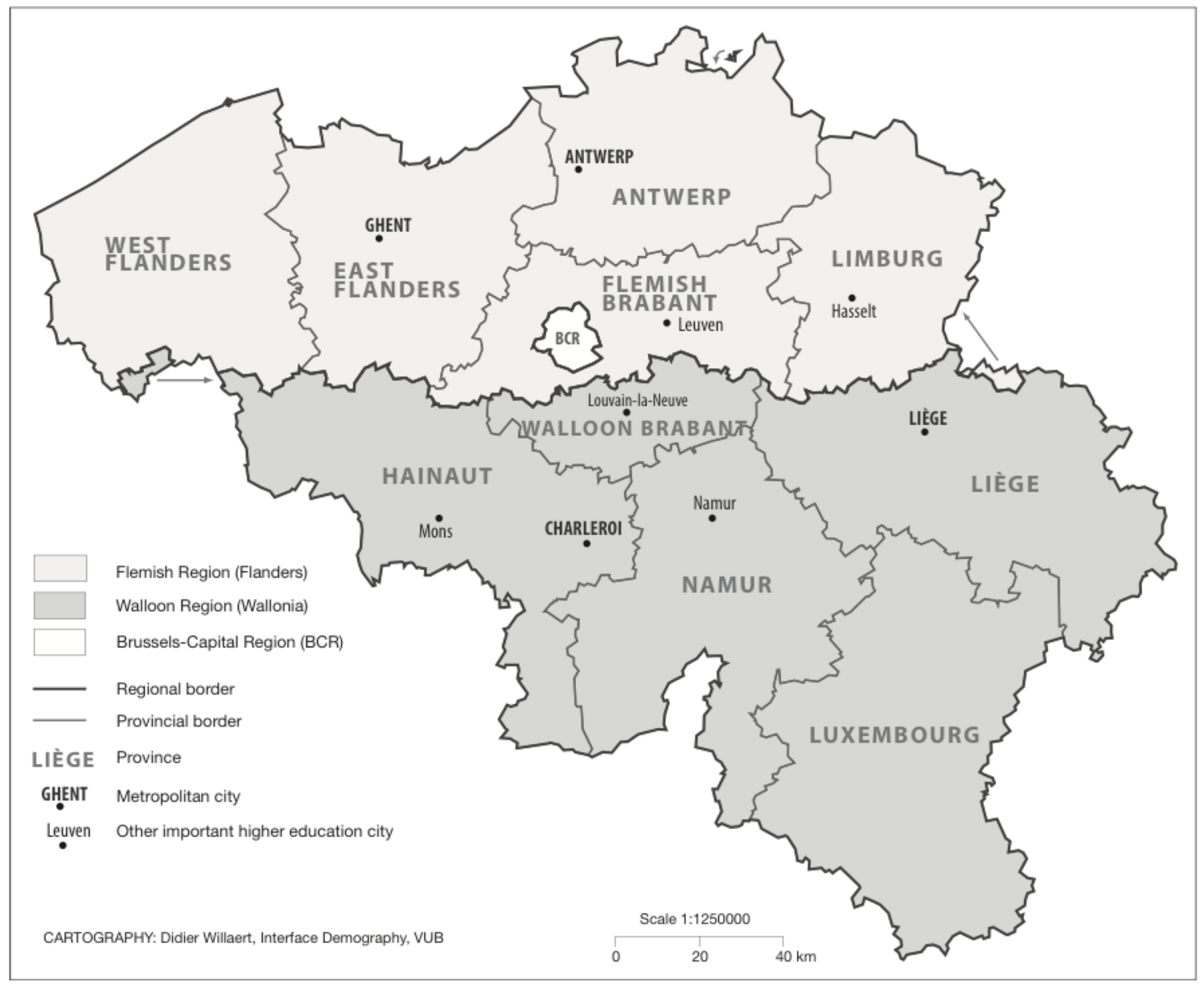

Spatial boundaries are according to the NUTS classification of the Local Administrative Units system as defined by the Commission Regulation No. 1059/2003, set up by Eurostat.

(1) Regions are NUTS-1 units. There are three regions in Belgium, i.e. Flanders, Wallonia, Brussels-Capital Region.

(2) Provinces are NUTS-2 units. Belgium constitutes 11 provinces, i.e. Antwerpen, Limburg, Oost-Vlaanderen, Vlaams-Brabant, West-Vlaanderen, Hainaut, Liège, Luxembourg, Namur, Brabant wallon, Brussels-Capital Region.

(3) Metropolitan cities are Brussels-Capital Region, Antwerp, Ghent, Charleroi and Liège. Regional cities are Aalst, Arlon, Brugge, Doornik, Genk, Hasselt, Kortrijk, La Louvière, Leuven, Mechelen, Mons, Namur, Oostende, Roeselare, Sint-Niklaas, Turnhout, 
Verviers. This distinction is based on the urban facilities/provisions and the extent to which these are used by local residents and/or non-local residents (Van Hecke et al., 2009). The spatial units are defined based on the municipalities, i.e. LAU-2 units, formerly NUTS-5. There are 589 Belgian municipalities. Populations range from 56 (Honnelles) to 445,570 (Antwerp), densities from 1 inh./sq.km (Honnelles) to 19,442 inh./sq.km (Saint-Josse-ten-Node, part of the Brussels-Capital Region). Table A1 provides some general characteristics of the largest higher education cities.

Table A1. Main characteristics of the largest higher education cities.

\begin{tabular}{|c|c|c|c|c|}
\hline HE cities & $\begin{array}{l}\text { Population } \\
(1 / 10 / 2001)^{\mathrm{a}}\end{array}$ & $\begin{array}{l}\text { Density } \\
(1 / 10 / 2001)^{a}\end{array}$ & $\begin{array}{l}\text { Job ratio } \\
(1 / 1 / 2006)^{b}\end{array}$ & $\begin{array}{l}\text { Wealth Index } \\
\text { (average 2004- } \\
2006)^{c}\end{array}$ \\
\hline Brussels-Capital Region ${ }^{e}$ & 964,405 & $\begin{array}{l}5,975 \\
\text { with municipal } \\
\text { values ranging } \\
\text { from } 1,903 \text { to } \\
19,442\end{array}$ & $\begin{array}{l}86 \text { with } \\
\text { municipal values } \\
\text { ranging from } 38 \\
\text { to } 232\end{array}$ & $\begin{array}{l}88 \text { with } \\
\text { municipal values } \\
\text { ranging from } 52 \\
\text { to } 114\end{array}$ \\
\hline Antwerp & 445,570 & 2,179 & 93 & 95 \\
\hline Ghent & 224,685 & 1,439 & 106 & 106 \\
\hline Charleroi & 200,233 & 1,962 & 68 & 79 \\
\hline Liège & 184,550 & 2,660 & 85 & 86 \\
\hline Namur & 105,248 & 599 & 87 & 101 \\
\hline Leuven & 88,581 & 1,564 & 113 & 119 \\
\hline Mons & 91,123 & 622 & 77 & 89 \\
\hline Hasselt & 68,373 & 669 & 109 & 113 \\
\hline Louvain-la-Neuve & 27,703 & 840 & 86 & 105 \\
\hline
\end{tabular}

Notes: ${ }^{\text {a }}$ Derived from the 2001 census, authors' calculations.

'Source: Vlaamse Arbeidsrekening, Job ratio as the annual average of 2006

'Source: Statistics Belgium; The Wealth Index is a summary index that compares the mean fiscal income per inhabitant of an administrative unit (here LAU-2) with the mean fiscal income of a Belgian citizen. The Wealth Index of Belgium is set equal to 100. An index value below 100 indicates that the mean income per resident within a specific municipality is below the national mean income. The opposite is true for index values of more than 100 .

'In this study, the Brussels-Capital Region constitutes of its 19 municipalities.

\section{References (Appendix A)}

Van Hecke, E., Halleux, J., Decroly, J., \& Mérenne-Schoumaker, B. (2009). Woonkernen en Stadsgewesten in een Verstedelijkt België (Monografie 9: Verstedelijking). Brussels: FOD Economie, K.M.O., Middenstand en Energie Algemene Directie Statistiek en Economische Informatie. 


\section{Appendix B. Descriptive statistics}

Table B1. Descriptive statistics of the entire 2001 student population $(\mathrm{N}=82,530 ; 19$ deceased young adults before first move excluded) and the mobile graduate population not officially domiciled in the higher education (HE) city in $2001(\mathrm{~N}=56,578)$; respectively used to model (1) graduates' residential mobility and (2) attractiveness of HE cities for mobile graduates.

\begin{tabular}{|c|c|c|c|c|}
\hline & \multicolumn{2}{|c|}{ 2001 Student population } & \multicolumn{2}{|c|}{ "Mobile graduate population } \\
\hline & $\mathrm{N}$ & $\%$ & $\mathrm{~N}$ & $\%$ \\
\hline \multicolumn{5}{|l|}{ HE City } \\
\hline Brussels-Capital Region & 16,620 & 20.14 & 9,281 & 16.40 \\
\hline Antwerp & 7,411 & 8.98 & 4,784 & 8.46 \\
\hline Ghent & 12,609 & 15.28 & 9,579 & 16.93 \\
\hline Charleroi & 1,399 & 1.70 & 697 & 1.23 \\
\hline Liège & 7,928 & 9.61 & 5,520 & 9.76 \\
\hline Namur & 2,464 & 2.99 & 1,622 & 2.87 \\
\hline Leuven & 8,961 & 10.86 & 6,972 & 12.32 \\
\hline Mons & 3,134 & 3.80 & 2,172 & 3.84 \\
\hline Hasselt & 2,597 & 3.15 & 1,852 & 3.27 \\
\hline Louvain-la-Neuve & 3,995 & 4.84 & 3,183 & 5.63 \\
\hline Other regional cities & 7,521 & 9.11 & 5,069 & 8.96 \\
\hline Small cities & 7,891 & 9.56 & 5,847 & 10.33 \\
\hline \multicolumn{5}{|l|}{ StudAcc } \\
\hline No & 57,815 & 70.05 & 36,224 & 64.02 \\
\hline Yes & 24,715 & 29.95 & 20,354 & 35.98 \\
\hline \multicolumn{5}{|l|}{$\operatorname{Res} 01$} \\
\hline Not in HE city & 68,448 & 82.94 & 56,578 & 100.00 \\
\hline In HE city & 14,082 & 17.06 & 0 & 0.00 \\
\hline \multicolumn{5}{|l|}{ Urban01 } \\
\hline Central city & 21,291 & 25.80 & 6,806 & 12.03 \\
\hline Agglomeration & 10,815 & 13.10 & 8,871 & 15.68 \\
\hline Banlieue & 14,462 & 17.52 & 11,717 & 20.71 \\
\hline Commuterzone & 16,217 & 19.65 & 13,227 & 23.38 \\
\hline Other BE municipalities & 19,745 & 23.92 & 15,957 & 28.20 \\
\hline \multicolumn{5}{|l|}{ EduPar } \\
\hline Low & 13,374 & 16.21 & 8,373 & 14.80 \\
\hline Intermediate & 19,733 & 23.91 & 13,956 & 24.67 \\
\hline High & 41,048 & 49.74 & 28,853 & 51.00 \\
\hline Unknown attainment & 7,385 & 8.95 & 5,396 & 9.54 \\
\hline \multicolumn{5}{|l|}{ OccupStat } \\
\hline White collar & 41,744 & 50.58 & 52,805 & 93.33 \\
\hline independent - managerial function & 15,207 & 18.43 & 10,829 & 19.14 \\
\hline Blue collar & 10,933 & 13.25 & 7,217 & 12.76 \\
\hline Unemployed - in search for job & 2,749 & 3.33 & 1,549 & 2.74 \\
\hline Unknown occupational status & 11,897 & 14.42 & 7,611 & 13.45 \\
\hline \multicolumn{5}{|l|}{ HE Type } \\
\hline Professional Bachelor & 40,643 & 49.25 & 27,055 & 47.82 \\
\hline Academic Bachelor & 10,865 & 13.16 & 7,484 & 13.23 \\
\hline Academic Master & 26,779 & 32.45 & 18,765 & 33.17 \\
\hline Postgraduate Master & 4,243 & 5.14 & 3,274 & 5.79 \\
\hline
\end{tabular}


Table B1. Continued

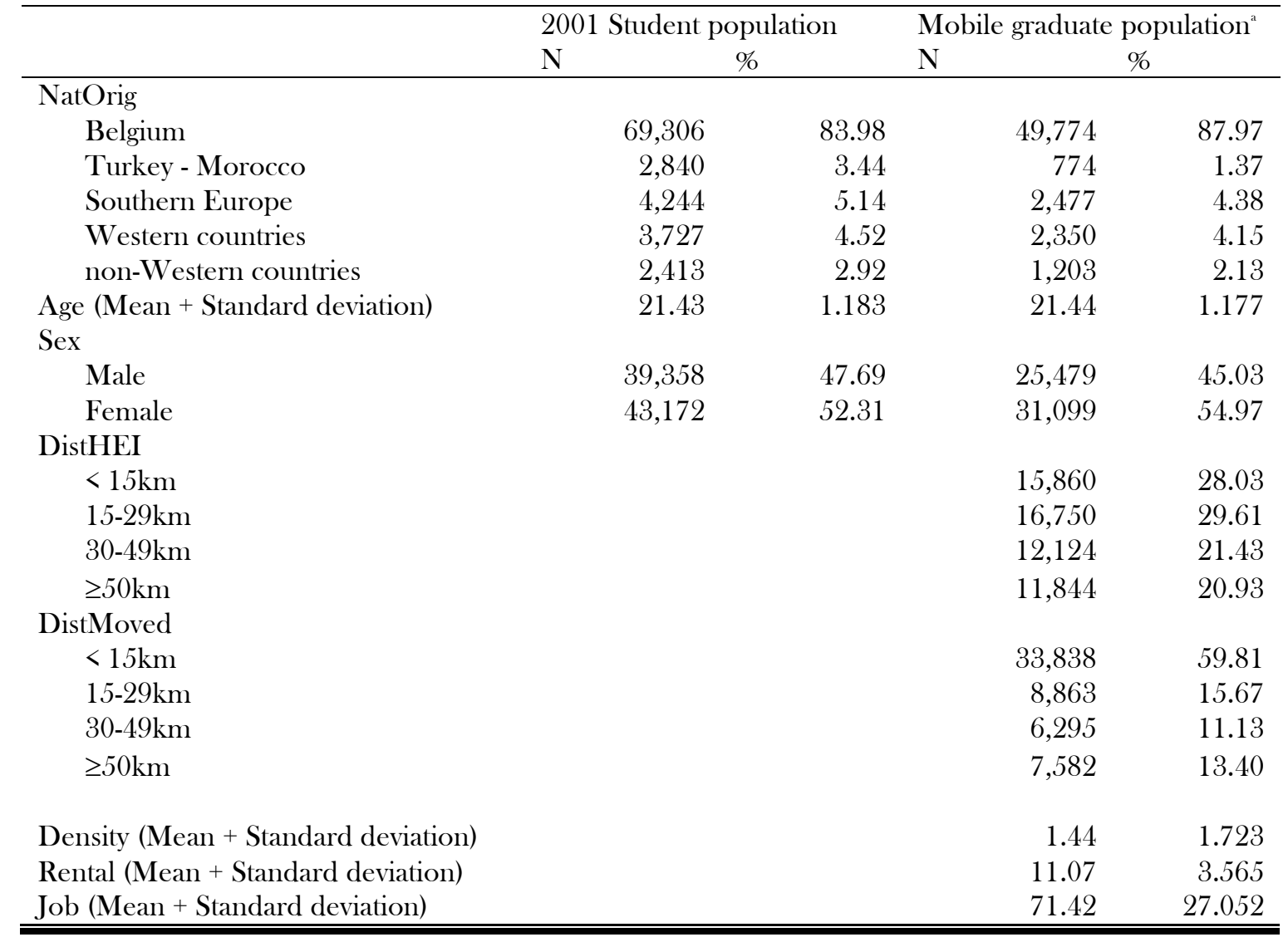

Notes: ${ }^{a}$ Residential mobility observed between 2/10/2001 and 1/1/2010.

Sources: Census 1991 and 2001 and National Register, authors' calculations 


\section{Appendix C. Cumulative survival curves at mean of covariates}

Figure C. Cumulative survival function for attracted graduate migrants $(\mathrm{N}=13,442)$, by city of higher education (HE) in 2001: (C1) model 1 includes HE institution (HEI) location and controls for age; and (C2) the final model includes HEI location and controls for demographic, socio-economic, residential and contextual characteristics.
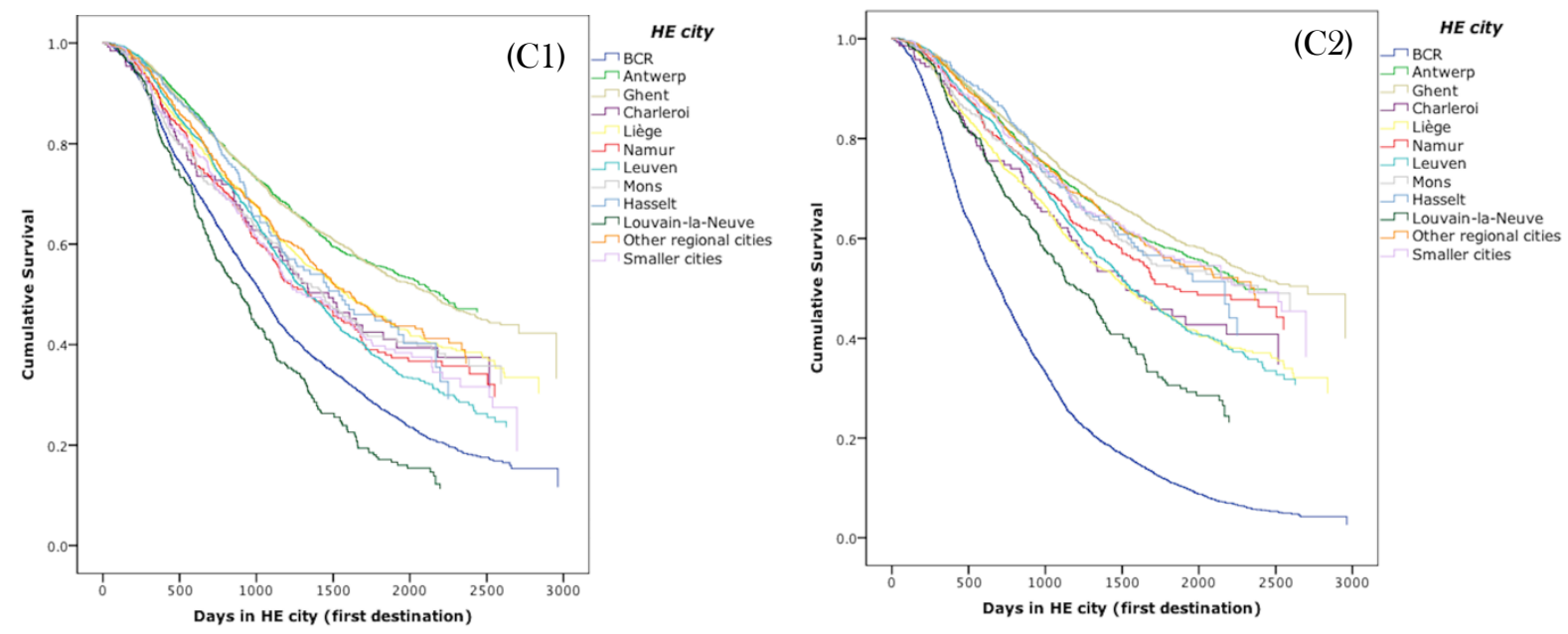

Sources: Census 1991 and 2001 and National Register 2001-10, authors' calculations 